\title{
ACHIEVEMENTS TO DATE AND EXISTING RESEARCH GAPS IN PROJECT MANAGEMENT IN THE LIGHT OF LITERATURE STUDIES
}

\author{
Dariusz MINDUR \\ Silesian University of Technology, Faculty of Organization and Management, Poland; dariusz.mindur@polsl.pl, \\ ORCID: 0000-0002-1069-5796
}

Purpose: The purpose of this article was to identify current development directions and potential research gaps in project management.

Design/methodology/approach: The method of systematic review of articles published in the Elsevier - Science Direct database in the years 2000-2019 was used, where the search phrase was "project management" and the type of articles was "research articles". In order to answer the research questions posed, an additional method of analysis and criticism of the literature was used.

Findings: The following conclusions were drawn from the analysis of the articles: a) almost a third of them concerned the practical application of PM issues in one clearly defined sector of the economy, with the most common reference being to the building sector and IS/IT, b) most articles were created in English-speaking countries $(47 \%)$, c) the largest number of articles concerned the area of human resource (HR) management, including many subjects of qualifications and leadership, d) of the ten areas of knowledge specified in PMBoK, "HR" and "scheduling/time" were the most popular, followed by risk-related issues.

Practical implications: The findings of this article would contribute to building a strong and coherent theory and identify best practices in project management.

Originality/value: The most important achievement is the recognition of two areas of knowledge - lean management and game theory - where little research has been done so far, and whose solutions and methods could be successfully implemented inside PM.

Keywords: Project Management; Research trends; Literature review

Category of the paper: Literature review

\section{Introduction}

Projects have accompanied humanity since the dawn of time, but modern project management emerged as a social practice only after World War II as a set of procedures, models and techniques (Hodgson and Cicmil, 2006), derived from operational research and focused on 
the development of planning and scheduling methods (Söderlund, 2004b). The above concept, which from the beginning had both ardent supporters and opponents, despite numerous debates, disputes and the recurring wave of criticism, was accepted as an indispensable element of economic development (Cicmil, and Hodgson, 2006) and quickly covered not only new geographical areas but it has also penetrated almost all industry sectors (Archibald, 2004). Unfortunately, despite mastering so many levels of social life, project management, until the end of the nineties, suffered from a lack of sufficient theoretical foundations (Koskela, and Howell, 2002) that would qualify them as a full-fledged field of science.

However, this state of affairs could not last long - project management has become a key business process for many companies and its economic significance has not ceased growing (Maylor, 2001). It quickly became clear, that the development of specific competences in this area can not only lead to the development of enterprises against the background of a rapidly changing market, but even be a necessary condition for their survival (Jugdev et al., 2001). The world of science has recognised the need to broaden and supplement the theoretical foundations and to integrate them into practical management (Söderlund, 2004).

Projects have ceased to be treated as independent enterprises or closed systems. To understand their variability, factors that guarantee success, causes of failure, impact on the surrounding business environment, it was necessary to put them in the right context both historical and organisational (Engwall, 2003) and to introduce a formal categorisation of their types (Shenhar, 2001). Two different approaches to project management were clearly outlined (Winter et al., 2006; Pollack, 2007): the first, hard, rooted in system theory, strictly focused on providing analytical models and planning techniques, concentrating on increasing performance and optimising elements "the iron triangle" - cost, time and scope. This approach - although having undoubted qualities of engineering precision, was criticised for too narrow view at the problems faced by practitioners.

As part of the second - soft approach - projects have gained a wider meaning and began to be perceived as complex social systems (Cicmil et al., 2006; Hodgson, and Cicmil, 2008), closely related to all processes in the organisation and providing - in addition to the requirements set - additional business values. Risk management, interactions between stakeholders and the efficient flow of information gained importance. It also became clear, that one of the important success factors of the undertaking is the proper selection of the project team and its skilful management.

There was a need to isolate and describe good practices and, finally, formal certification of emerging knowledge. Certification programmes, due to their high efficiency, soon gained huge popularity (Morris et al., 2006). Already since the sixties, the first attempts to communicate between profession experts and the formation of the first project management societies could be observed. In the eighties, the Project Management Institute (PMI) began its certification programme, and not long after the British Association for Project Management (APM) 
(Morris et al., 2006b). Soon, there was a rapid development of such associations around the world (Morris et al., 2011).

Projects are currently making a significant contribution to the global economy. They are used in every industry - both private and public enterprises, government institutions and non-profit organisations. They are important instruments used to shape the company's strategy (Gareis, and Huemann, 2007).

Interest in research in project management has increased over the past twenty years (Turner et al., 2013), which is reflected in the number of articles published. This increase is caused by many factors - ranging from growing competition in global markets, shortening product life cycles, increasing globalisation, through the increasing access to information and training, and ending with the rapid development of supporting software (Gareis, and Huemann, 2007).

Unfortunately, many authors still view project management as a weak and immature concept. They notice its insufficiently developed theoretical foundations. They postulate to expand the scope of research and then to organise knowledge properly. Perhaps - as some believe - due to the one-time and unique nature of the projects, as well as their multidimensionality and context dependence, one coherent theory will never arise (Hall, 2012; Smyth, and Morris, 2007).

Bearing in mind the above circumstances, this article attempts to identify current trends in project management development - indicating both fashionable and neglected trends, searching for gaps in the existing area of knowledge, and thus formulating new research problems that need to be developed and supplemented.

\section{Research to date}

Many authors have recognised the need to broaden and deepen the theoretical foundations of project management.

Morris et al. (Morris et al., 2000) listed the main research trends in the search for issues in which future staff dealing with the PM area should be educated. Their goal was to review the current knowledge of the British Association for Project Management Body of Knowledge (APMBoK) and to propose key changes in its next release. They noticed, that the existing BoK structure was created without sufficient empirical data that could justify its current shape. They noticed discrepancies in the perception of the scope and boundaries of project management between various groups of practitioners and the ongoing debate in this field.

A similar divergence of views was noted by Themistocleous and Wearne (Themistocleous, and Wearne, 2000), who, in their work, analysed articles published in the years 1984-1998 in IJPM (International Journal of Project Management) and PMJ (Project Management Journal) 
in order to isolate the leading research directions concept. They noticed that specific topics with different intensity are described in both journals.

Artto and Wikstrom (Artto, and Wikstom, 2005) identified eleven thematic blocks classifying projects from the organisation's point of view. They showed that there is a need to expand the theoretical foundations of project management in the areas of: organisation theory, innovation theory and sociological and psychometric theories.

Bredillet (Bredillet, 2006) made a significant contribution to understanding project management and its dynamics, which used the EBSCO Business Source Premier Database to conduct keyword analysis to identify important development directions for PM. His research showed incessant interest in cost management, information management and optimisation techniques, and in the strategic aspect - project categorisation issues, integration with supply chain management and knowledge management.

Crawford et al. (Crawford et al., 2006), using a similar method, examined 1051 articles published in the years 1994-2003 in IJPM and PMJ and compared the obtained results with the earlier works of other authors. They noticed, similar to Themistocleous and Wearne before (Themistocleous and Wearne, 2000), the difference in approach to different topics between both journals. They found a reduction of interest in interpersonal and quality issues, as well as an increase in the importance of project evaluation and improvement. They also noticed an increase in the strategic importance of the project.

Similarly, later, Kwak and Anbari (Kwak, and Anbari, 2009) identified the strategic importance of the project as a leading direction when it comes to developing project management. They analysed this concept in terms of its relationship with related fields through a review of 537 articles that appeared in the years 1950-2007 in 18 business journals, excluding those that were mainly devoted to the subject of PM. The articles were grouped into eight categories. The authors have shown a strong increase in PM research in all areas since the 1980s.

The increase in the number of quantitative studies was noticed by Biedenbach and Müller (Biedenbach, and Müller, 2011), who used a priori classification method and systematically reviewed the materials collected as part of the IRNOP (International Research Network on Organizing by Projects) conference in the years 1994, 2000 and 2007, in order to identify philosophical currents and research trends within PM.

In their extensive work, Pollack and Adler (Pollack, and Adler, 2015) analysed 94,472 publications from the Scopus and ISI Web of Science databases, which appeared in the years 1962-2012, in search of dominant research topics related to project management. They used a number of methods, such as field analysis, co-occurrence frequency and rate of change of words with respect to article abstracts and keywords. They noticed, among others, the growing importance of issues related to strategic planning, knowledge management and the role of PM in the organisation, e.g. Crawford et. al (2006); Kwak and Anbari (2009). 
Svejvig and Andersen (Svejvig, and Andersen, 2015) conducted a systematic review of 74 publications related to the RPM (Rethinking Project Management) trend and showed its emergence over the years since the early 1980s.

Uchitpe et al. (Uchitpe et al., 2016) analysed the keywords of the articles published in the IJPM (International Journal of Project Management) over the years 2009-2013 to forecast the directions of research development within PM in the coming years. One of their observations was a great interest in the subject of organisational culture and its impact on the success of the project.

Padalkar and Gopinath (Padalkar, and Gopinath, 2016) had a similar goal. They systematically reviewed articles mainly from IJPM, PMJ and IJMPB (International Journal of Managing Projects in Business) and then divided them into four separate thematic areas: deterministic, non-deterministic, seeking explanation and general issues. They noticed little interest in communication in the project, as well as issues related to quality management, integration and scope, although - as the authors themselves emphasised - these factors often appeared in many publications as the reasons for the failure of the project.

There is an undoubted need for further analysis of the project management area. Identification of development directions and research gaps that have not been sufficiently treated so far can contribute to building a strong and coherent theory, as well as identifying best practices within this subdiscipline of management sciences.

\section{Research method}

The purpose of this article is to identify research gaps and further research directions in project management, based on a literature review covering the genesis and development of this management subdiscipline. To do this, the following questions were asked:

- How has the PM area developed over the past twenty years?

- Which directions have lost their importance, and which are currently dominant?

- In which sectors of the economy is research currently being conducted?

- Which countries contribute to project management the most?

- What research gaps in project management currently need to be filled in economic theory and practice?

The method of systematic review of articles published in the Elsevier - Science Direct database in the years 2000-2019 was used in the work. The search was based on the phrase "project management", type of articles "research articles", resulting in 16,662 publications, of which 480 articles were selected for further analysis using "relevance" sorting. 
The articles have been grouped based on:

- year of publication,

- country of origin,

- sector of economy/industry,

- area of knowledge.

The priori classification of knowledge areas was made on the basis of: Crawford et al., 2006; Pollack, and Adler, 2015; Padalkar, and Gopinath, 2016; Project Management Institute, 2013; and was presented in Table 1.

\section{Table 1.}

A priori areas of knowledge

\begin{tabular}{|c|c|c|}
\hline No. & Area of knowledge & Description \\
\hline 1 & Integration & \multirow{10}{*}{ Based on PMBoK (Project Management Institute, 2013). } \\
\hline 2 & Scope & \\
\hline 3 & Schedule/Time & \\
\hline 4 & Costs & \\
\hline 5 & Quality & \\
\hline 6 & HR & \\
\hline 7 & Communication & \\
\hline 8 & Risk & \\
\hline 9 & Procurement & \\
\hline 10 & Stakeholders & \\
\hline 11 & Organisation & $\begin{array}{l}\text { The role PM plays in shaping the organisation, increasing its efficiency and } \\
\text { market competitiveness; } \\
\text { The impact of the organisational environment on the project - its course and } \\
\text { conditions for success (organisational culture, mission, vision, values, } \\
\text { attitudes, technological advancement of the company, the presence of IT } \\
\text { systems etc.) } \\
\text { Organisational maturity in the field of PM (maturity models, maturity } \\
\text { assessment etc.) } \\
\text { Project support offices in the organisation. }\end{array}$ \\
\hline 12 & Tools/Techniques & $\begin{array}{l}\text { Tools, techniques, methods, good practices, standards. } \\
\text { The role of standardisation and certification in the PM area. }\end{array}$ \\
\hline 13 & Portfolio/Programme & $\begin{array}{l}\text { Multiple project management. } \\
\text { Project portfolio management. } \\
\text { Project programme management. }\end{array}$ \\
\hline 14 & Performance & $\begin{array}{l}\text { Issues of efficiency and effectiveness of the project process, mainly in relation } \\
\text { to implementation processes, as well as monitoring and controlling. }\end{array}$ \\
\hline 15 & Success factors & $\begin{array}{l}\text { Factors affecting the success/failure of a project, mainly relevant in the area of } \\
\text { initiation and planning processes. }\end{array}$ \\
\hline 16 & Strategy & $\begin{array}{l}\text { Project strategy as an important factor of success. } \\
\text { Concurrency of the project's goal with the organisational strategy. }\end{array}$ \\
\hline 17 & RPM & "Rethinking Project Management". \\
\hline 18 & Theory building & Publications aimed at discovering research directions within PM. \\
\hline 19 & Education & $\begin{array}{l}\text { Issues related to education within PM (fields of study, certification } \\
\text { programmes etc.) }\end{array}$ \\
\hline 20 & $\begin{array}{l}\text { Knowledge } \\
\text { management }\end{array}$ & $\begin{array}{l}\text { All issues of acquiring, collecting and managing knowledge in the context of } \\
\text { both the project and the organisation. }\end{array}$ \\
\hline
\end{tabular}

In order to answer the research questions posed, an additional method of analysis and criticism of the literature was used. 
Specifying the purpose

Formulating a research task, the implementation of which will prove helpful in building a uniform and coherent theory of project management.

\section{Asking research questions}

- How has the PM area developed over the past two hundred years?

- Which directions have lost their importance and which are currently dominant?

- In which sectors of the economy is research currently being conducted?

- Which countries contribute to project management the most?

- What research gaps can be identified?

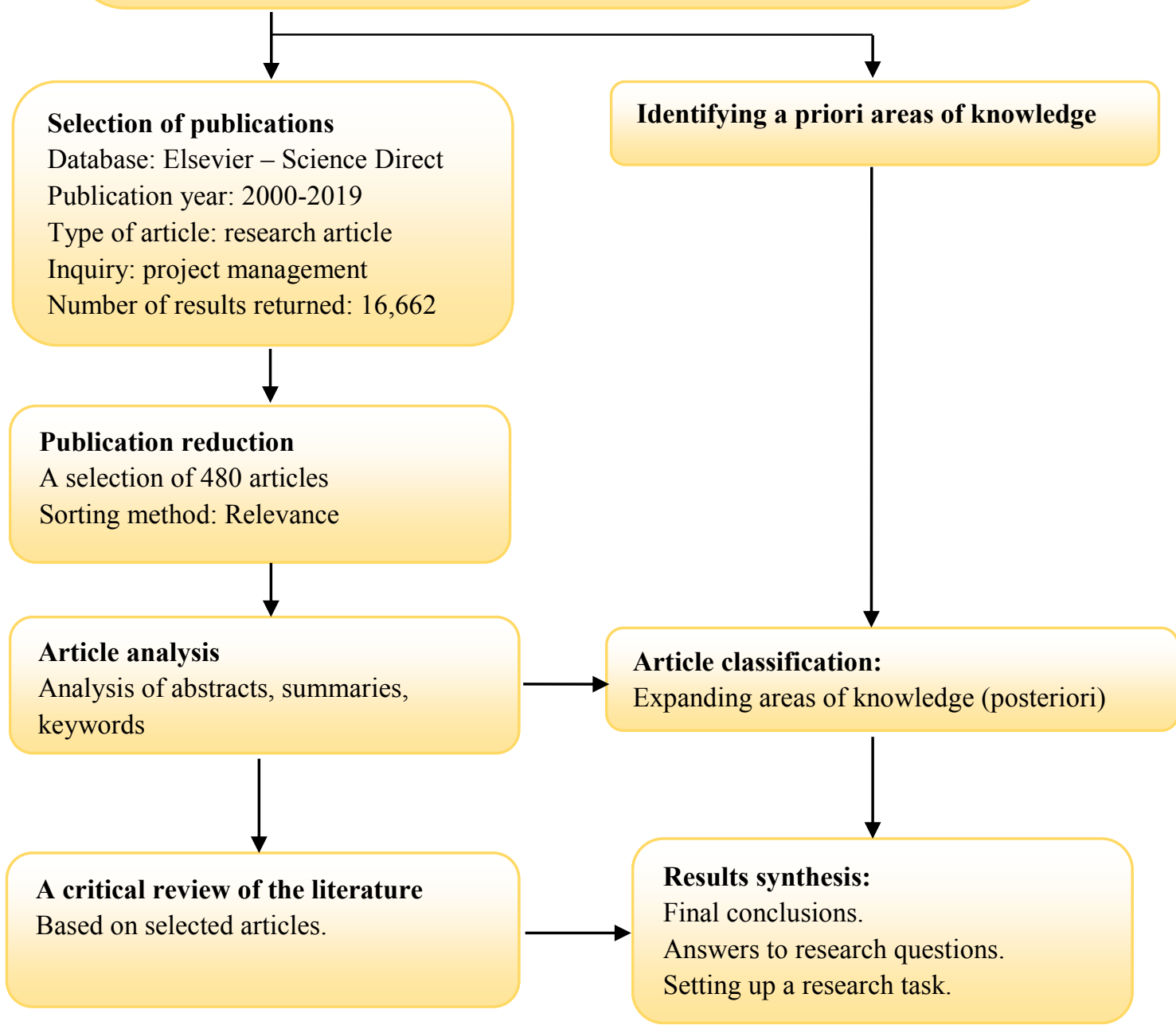

Figure 1. Research method. Source: own study. 


\section{Results}

The study included 480 articles on project management published in the Elsevier Science Direct database in the years 2000-2019.

The number of articles published annually from the period 2000-2011 oscillates between 6 and 20. Most articles come from the period 2012-2017 and are in the range of 36 to 62 per year. There are 24 articles from 2018 and 14 from 2019. The summary of the number of publications in individual years is shown in Figure 2.

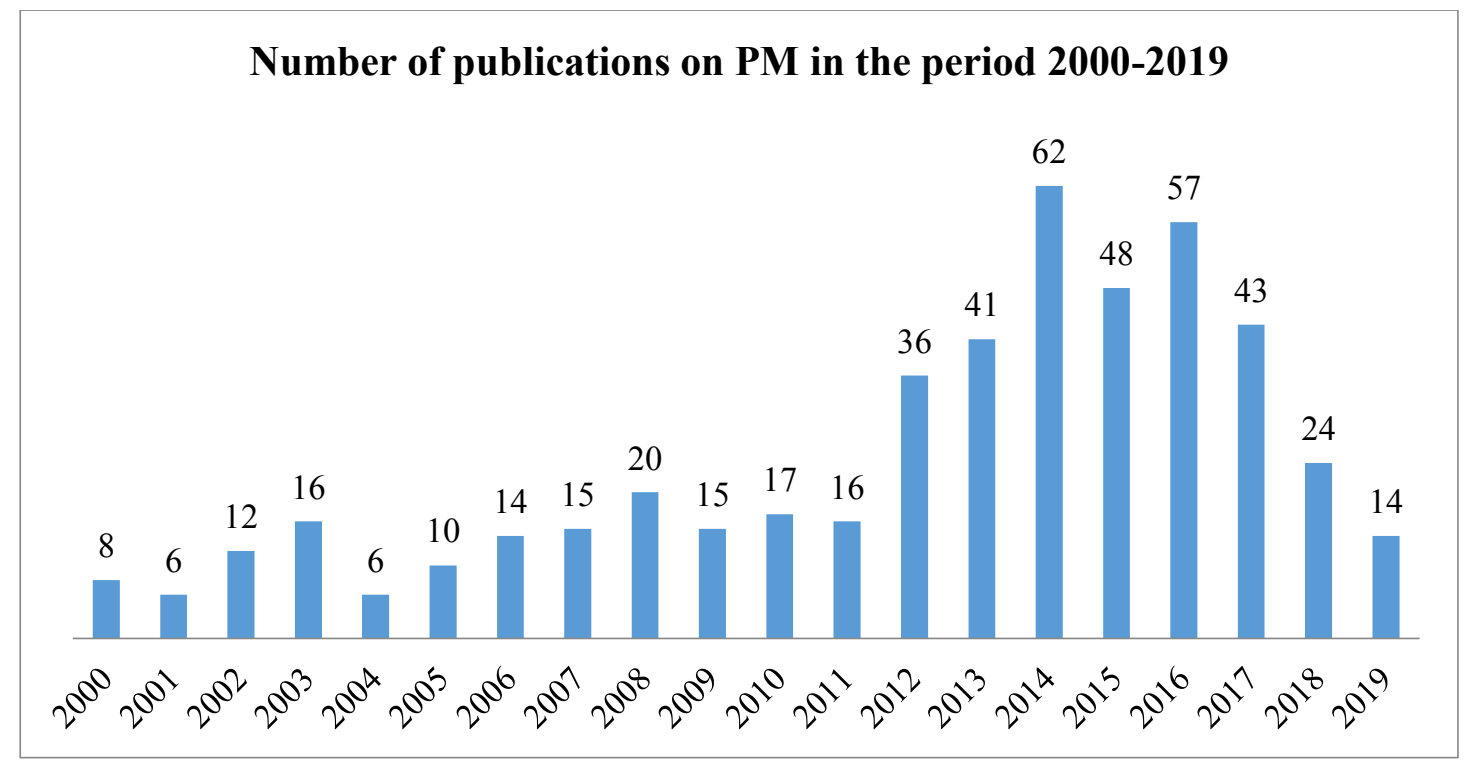

Figure 2. Number of publications on PM in the period 2000-2019. Source: own study.

Almost a third of articles (154 of 480) refer to one clearly defined economic sector. Others (326 of 480) raise universal topics for PM. Most articles concern the construction and building industry (48 articles) and information techniques (48 articles), while in the last group, as many as 20 articles concern software development. Another 14 articles concern the manufacturing industry (including the automotive industry -4 articles, metal processing 1 article). Other fields have 6 or fewer articles and in succession are: fuel sector, transport, health care, education and learning, public sector, finance and banking, water management, energy, infrastructure, research and development institutes, shipbuilding, multimedia, electrical industry, defense industry, chemical industry, architecture, aviation industry and advertising. A summary of publications in individual sectors is presented in Figure 3.

59 different trade journals were identified, in which topics related to project management were discussed. The most publications were published in journals: International Journal of Project Management (193 articles), Procedia - Social and Behavioral Sciences (76 articles), Procedia - Computer Science (45 articles), Procedia - Technology (17 articles), Procedia Economic \& Finance (12 articles), Automation in Construction (11 articles), The Journal of Systems and Software (10 articles). In other journals, 8 or fewer articles were identified. 
A summary of the number of publications on PM in the period 2000-2019 by trade journals is shown in Figure 4.

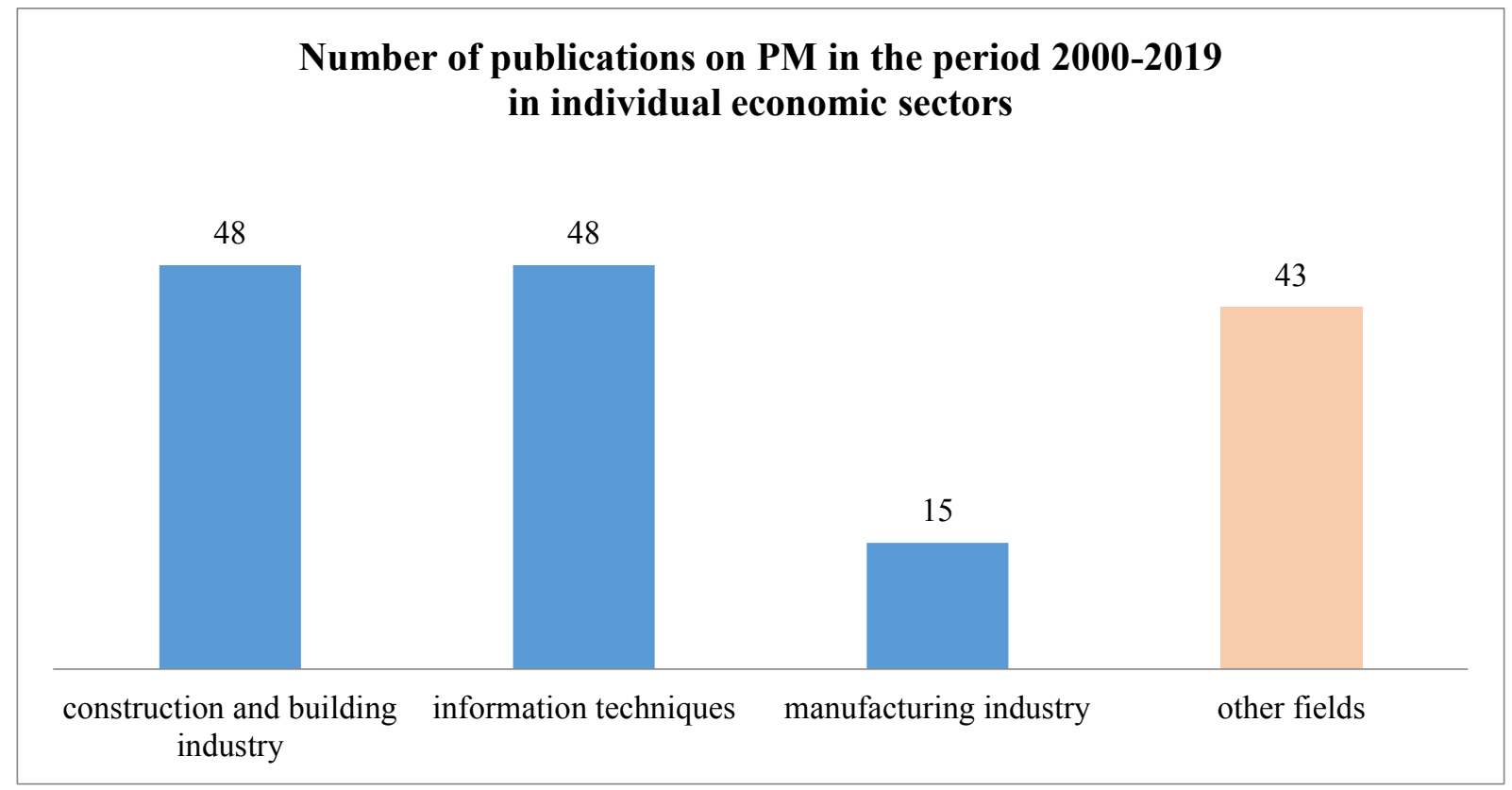

Figure 3. Number of publications on PM in the period 2000-2019 in individual economic sectors. Source: own study.

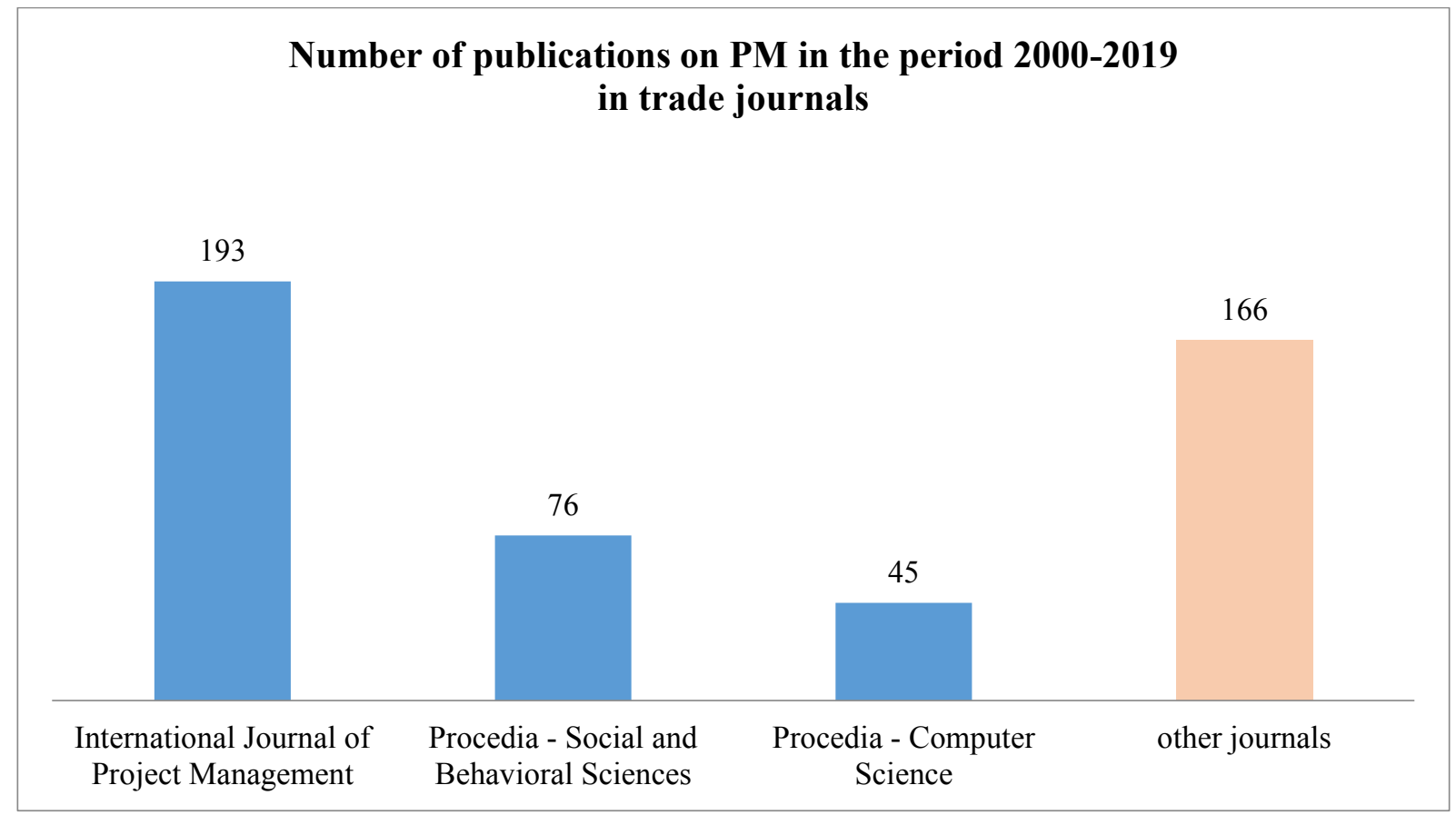

Figure 4. Number of publications on PM in the period 2000-2019 in trade journals. Source: own study.

60 countries were identified, in which topics related to project management were raised. Most publications were made in English-speaking countries: England (56 articles), United States (50 articles), Australia (47), Canada (29) - which represented almost half (47\%) of all sources analysed. The next countries are Portugal (26 articles), France (25 articles), Spain (25 articles), Germany (25 articles), Brazil (24 articles), China (24 articles), Sweden (21 articles), Norway (15 articles), Taiwan (14 articles), Finland (13 articles) and the 
Netherlands (12 articles). In other countries, the number of identified publications is less than 10. A summary of the number of publications on PM in the period 2000-2019 by country (for countries where the number of publications was not less than 10) is presented in Figure 5.

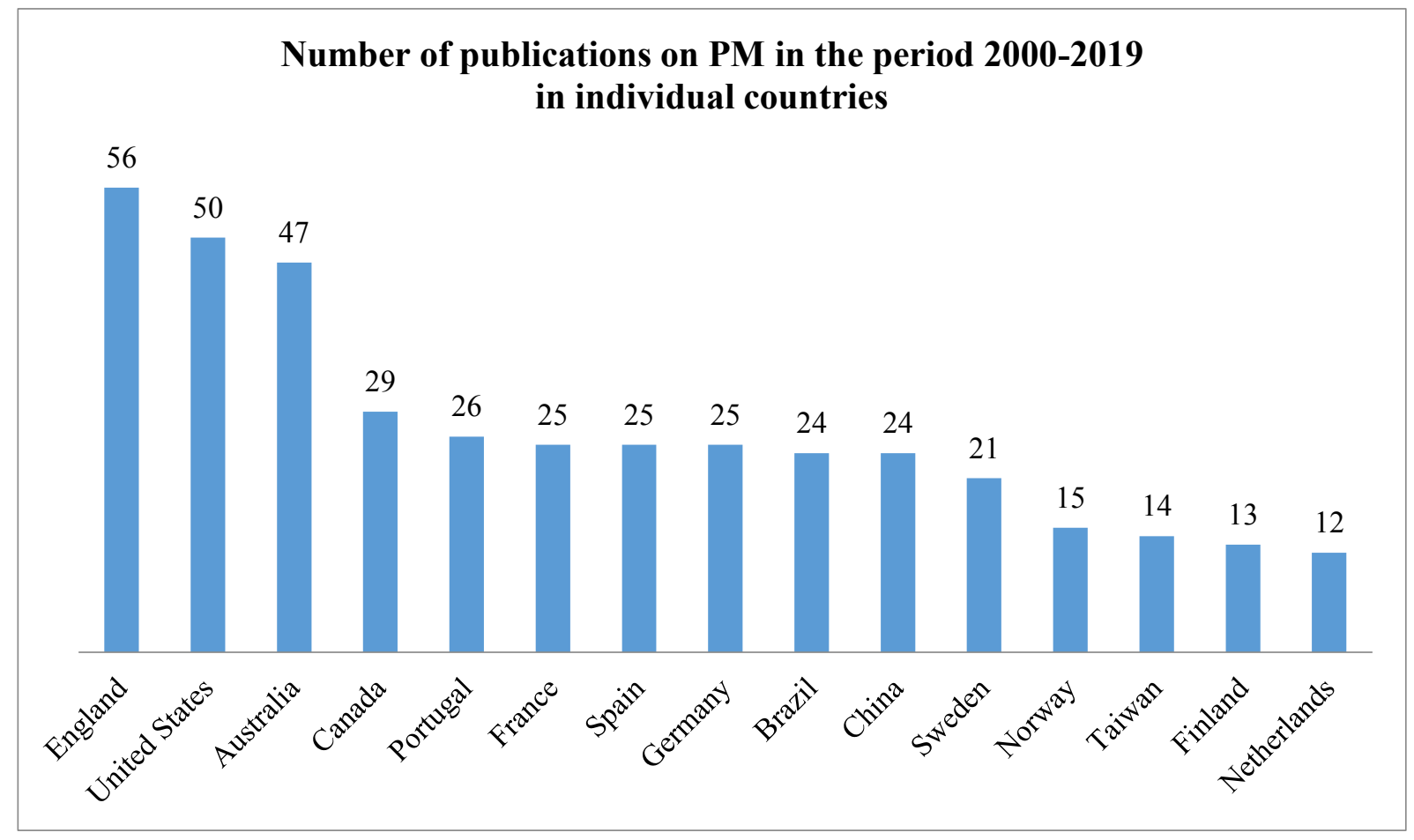

Figure 5. Number of publications on PM in the period 2000-2019 in individual countries. Source: own study.

In addition to the twenty areas of knowledge defined a priori, an additional six areas were identified, for which the number of publications was not less than 10. These are:

- PMIS (40 articles) - Project Management Information Systems - IT systems supporting the planning, monitoring and controlling of project management processes.

- Decision support (28 articles) - techniques and methods of decision support and their implementation within PMIS.

- Complexity (17 articles) - problems arising from the complexity of projects.

- Innovations (17 articles) - innovation management in PM.

- Sustainability (15 articles) - issues of social, economic and ecological impact of projects on the environment.

- Benefits (11 articles) - tangible and intangible, long and short term benefits resulting from the implementation of the project (but excluding issues related to cost management).

A summary of the number of publications on PM in the period 2000-2019 by knowledge areas is presented in Figure 6.

Within the "Tools/Techniques" area, three subgroups were identified, in succession referring to: agile methodologies (19 articles), standardisation (13 articles) and certification (6 articles). 
Within the "Organisation" area, four subgroups were identified, in succession referring to: the impact of PM on organisation (30 articles), organisational maturity (19 articles), project management offices - PMO (18 articles) and the influence of the environment on PM (16 articles).

Figure 7 shows the number of publications in relation to knowledge areas defined in PMBoK (Project Management Institute, 2013).

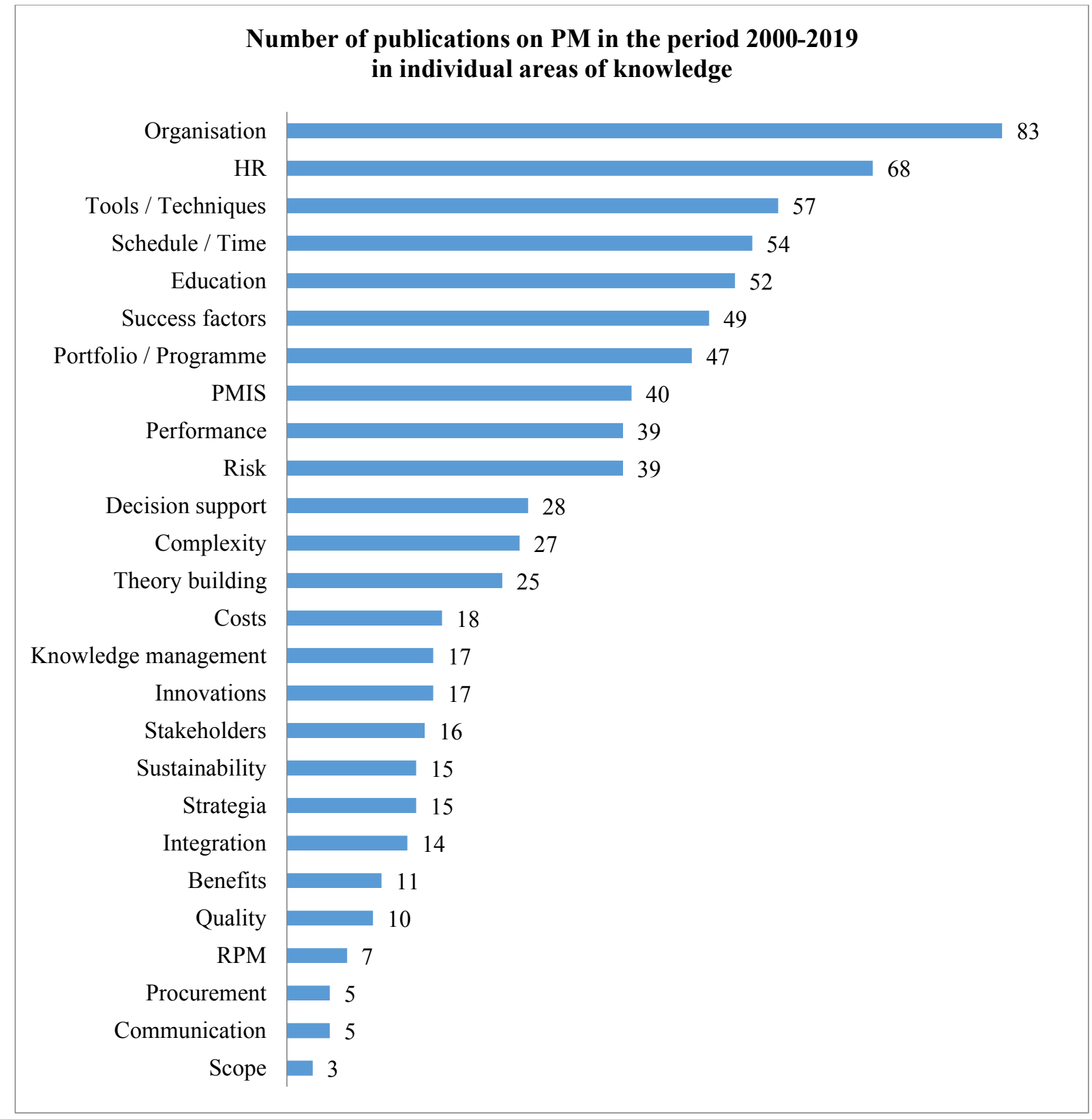

Figure 6. Number of publications on PM in the period 2000-2019 in individual areas of knowledge. Source: own study. 


\section{Number of publications on PM in the period 2000-2019 in relation to knowledge areas defined in PMBoK}

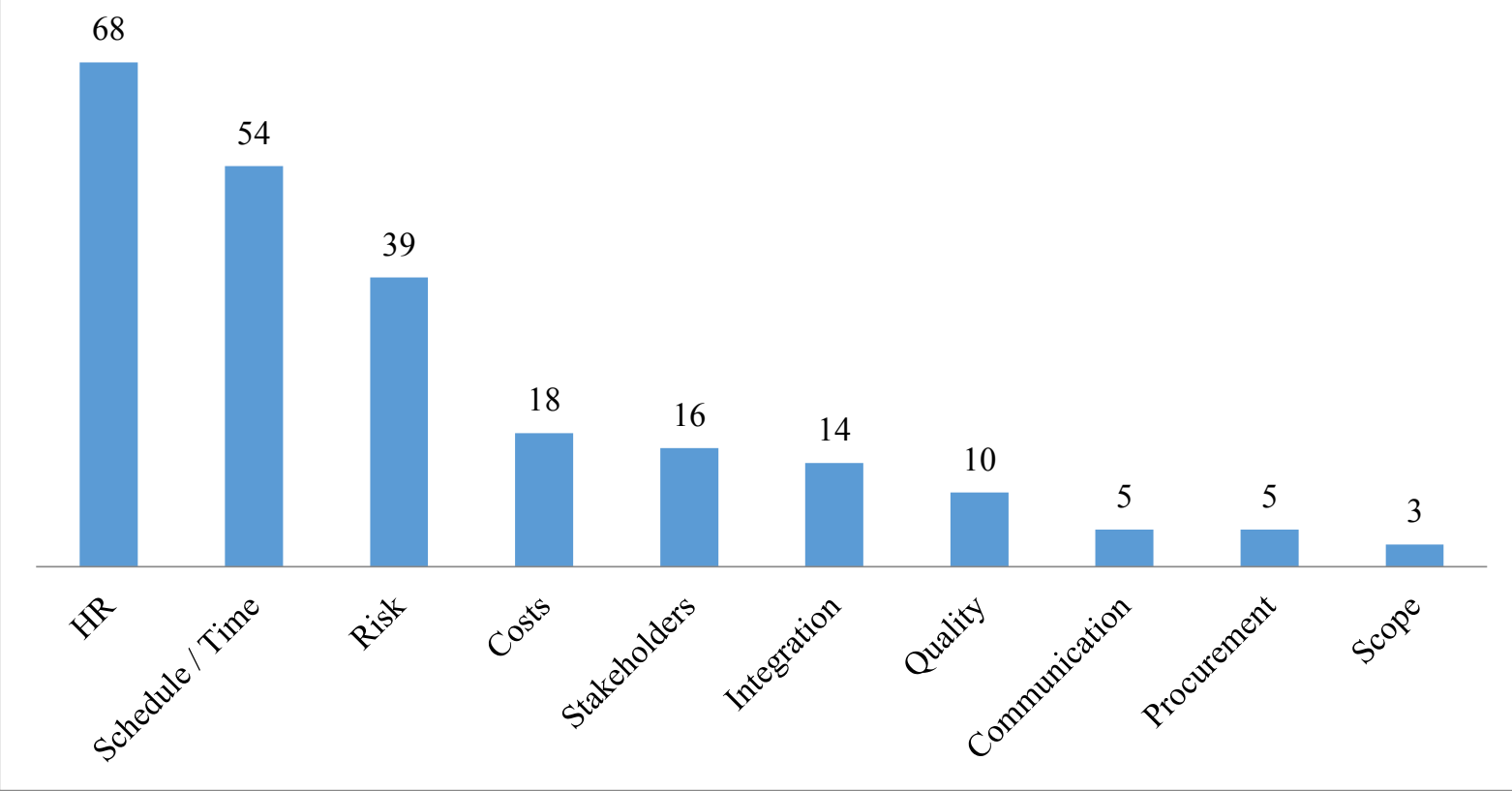

Figure 7. Number of publications on PM in the period 2000-2019 in relation to knowledge areas defined in PMBoK. Source: own study.

\section{Discussion}

Project management has enjoyed unflagging interest in recent years, as proven by the large number of publications in this area. This is understandable, because PM has become an important element of the organisational environment, guaranteeing survival in changing market conditions, by achieving long- and short-term goals (Hyväri, 2006). Such great importance for the developing economy is conducive to the spread and institutionalisation of this subfield (Calabrese, and Mastroberardino, 2015). Unfortunately, despite its development, practitioners are constantly struggling with many problems, such as exceeding deadlines (Rivera, and Kashiwagi, 2016; Ingasona, and Shepherd, 2014) or the budget (Doloi, 2011) during the implementation of various investments. That is why the integration of theoretical research with a practical business approach becomes such an important topic (Söderlund, and Maylor, 2012). In the area of project management, one can observe constant changes of perspectives (Kolltveita et al., 2007) and interests, one should try to identify the main directions and research gaps in order to build a strong and coherent theory.

The pragmatic nature of project management is demonstrated by the large number of publications dealing with the development and implementation of solutions within specific sectors of the economy (nearly a third of the articles analysed), most of which concern the 
building industry and information technologies. Focusing on these two sectors may result from their specific nature - work within them focuses on the implementation of one-off ventures, with unique and strictly defined start and end dates. The complexity of construction projects and the need to participate in their implementation of many different entities (Van Der Velde, and Van Donk, 2002) is the source of many problems and, as a consequence, a significant percentage of failures. It is currently an important issue, due to the large economic dimension and social significance of this type of implementation (Eriksson et al., 2017). In turn, IT industry projects are a powerful tool, supporting the creation of economic value within an organisation, and their success is part of building a competitive advantage (Sanchez et al., 2017; Chmielarz, and Zborowski, 2018; Gomes, and Romão, 2016). This developed economic value, largely derived from small and medium-sized enterprises (Turner et al., 2010) is the building block of global economic capital.

Competition between companies in providing high quality products and services is now a common phenomenon. This necessitates the search for new solutions, not only in the technological sphere, but also in the process and management sphere, as well as mutual integration of all these elements (Mossalama, and Arafab, 2017). Perhaps for this reason, the relationship between organisation and PM is the most frequently discussed topic in the analysed group of articles. Institutions that successfully shape a culture based on projects, mainly by raising employee awareness (Rehor, and Vrchota, 2018), noticeably stabilise their market position (Do Carmo Silva, and Simoes Gomes, 2015).

The second trend, that has been observed in the researched publications, is the role of building and shaping human capital. The main reason for this may be the seeking of success and high efficiency of the project in this area (Brown et al., 2007) and especially in raising employee competences (Ekrot et al., 2016; Saidoun, 2016) - as many as 37 articles deal with competence, with the main emphasis being placed on the role of leadership and managerial skills (Hyväri, 2016; Cooke-Davies, and Arzymanow, 2003) (15 articles). Several publications have focused on gender as an element affecting the way of management (Okoro, 2016; Bilgin et al., 2017; Legault, and Chasserio, 2012) and the importance of inter-cultural differences in building project teams (Lückmann, and Färber, 2016; Vlahov et al., 2016; Pheng, and Leong, 2000; Zwikael et al., 2005). It should be added, that the differences shown are considered as favourable and contributing factors to the way the project is conducted.

Scheduling (including time management) is another of the ten areas of knowledge specified in PMBoK (Project Management Institute, 2013), which enjoys great interest among project management practitioners. It should be noted, that the sum of publications within HR and Scheduling is higher than in the other eight areas combined.

A greater share of articles on risk was expected in the projects, as it was characterised as significant in the period 2000-2015 in the work of Padalkar, and Gopinath (Padalkar, and Gopinath, 2016), and as one of the main trends in the period 2006-2012 in the work of Pollack and Adler (Pollack, and Adler, 2015). It also seems that some of the project failures are 
due to neglect in this matter (Masár et al., 2019; Teller, and Kock, 2013; Khameneh et al., 2016). Articles dealing with uncertainty in the project (11 articles) have also been included in this area, as there is a close relationship between uncertainty and risk (Lachhab et al., 2017).

Few publications related to quality management (10 articles), communication ( 5 articles) and scope (3 articles).

An interesting thematic area was identified, which is the application of game theory (GT) in project management. Mathematical modeling was identified as popular within the analysed publications (26 articles); however, there is little about game theory (De Magalhães et al., 2015; Bočková et al., 2015; Bočková, 2015) and the existing ones are rather descriptive and do not use the potential of this subfield. This fact may come as a surprise, as the topics in which GT mechanisms and solutions can be successfully applied are repeatedly raised. Such topics include: modeling competition and relationships between specific entities (both real and abstract) (Chen et al., 2018; Bindera et al., 2014; Yan et al., 2000; Marquès et al., 2011; Viglioni et al., 2016; Liang, 2009, 2010; Yang, and Lin, 2013; Chang, and Ishii, 2013), issues of resource limitation and allocation (Lim et al., 2011; Almarri, and Gardiner, 2014; Ponsteen, and Kusters, 2015; Jugdev et al., 2007), strategy implementation (Vilhelmsdottir et al., 2016; Martin, 2000) or support decision making (Fallah-Mehdipour et al., 2012; Al-Harbi, 2001).

Although such a large number of articles relate to the building industry, there has been little interest in issues related to legal issues. Only two articles have been identified regarding safety (Åsgård, 2018) and occupational risk (Badri et al., 2012).

Several works concerned lean management. Although this is a philosophy derived from production engineering, its principles can help increase the efficiency and effectiveness of ongoing projects (Heigermoser et al., 2019), especially if they are integrated with other approaches, such as agile methodologies (Sohi et al., 2016; Rivera, and Kashiwagi, 2016) or Six Sigma (Tenera, and Pinto, 2014).

Only eight articles raised the issue of research and development projects. This is not much, taking into account the large contribution to the global economy of this type of undertakings (Žarković et al., 2014) and their significance in the context of acquiring external knowledge (Vicente-Oliva et al., 2015), needed by organisations to raise market competitiveness. This is strange, because many other publications raised the topic of innovation and its importance (Geraldi et al., 2008; Ahn et al., 2010).

\section{Conclusions}

Project management has become an important business process for many organisations. Its proper use significantly increases the market competitiveness of enterprises, which often determines not only their stability, but even the possibility of surviving in an environment of 
rapidly changing economic conditions. That is why it has become so important to correctly identify relevant research areas within PM. Conducted research should build proper knowledge in order to finally raise the competences of managers and entire project teams, which will ultimately lead to increasing the efficiency and reliability of conducted ventures.

The purpose of this article was to identify current development directions and potential research gaps in project management, so as to contribute to building a strong and coherent theory and to identify the best practices within this subdiscipline of management sciences.

An analysis of 480 articles on project management was carried out, published in the Elsevier - Science Direct database in the years 2000-2019, from which the following conclusions were drawn:

- almost a third of the articles concerned the practical application of PM issues in one clearly defined sector of the economy, with the most common reference being to the building sector and IS/IT,

- most articles were created in English-speaking countries (47\%),

- the largest number of articles concerned the area of human resource (HR) management, including many subjects of qualifications and leadership,

- of the ten areas of knowledge specified in PMBoK, "HR" and "scheduling/time" were the most popular, followed by risk-related issues - topics in other areas were sporadically addressed.

The analysis identified several interesting areas of knowledge, in which little research has been carried out so far and whose development can positively influence the building of a strong theory of project management and help solve a number of practical problems faced by PM specialists.

One of the identified research gaps is the use of the lean management approach in project management, which is successfully and widely used in manufacturing companies. The assumptions of this philosophy (reducing waste, looking at management from the customer's point of view, continuous improvement) and its accompanying methods and tools (Kaizen, Just In Time, SixSigma) can significantly increase the efficiency of project implementation, and thus increase the likelihood of success and satisfaction of parties interested. Lean management is more than a management concept and its best practices have been developed for decades in the world's largest organisations. Despite this, few attempts have been made to synthesise these two areas so far. Further research is planned to carry out a thorough analysis of lean management solutions and the possibilities of their implementation as part of project management.

Game theory is another interesting but underdeveloped area of knowledge within PM. Although a number of problems were identified, in which its mechanisms could be successfully applied (support in reaching decisions, resource allocation, critical path analysis, competition modeling between entities etc.), little research was found in this area. As part of further 
research, it is planned to analyse mathematical models, algorithms and concepts developed inside GT and then try to adapt them inside PM.

Further research, both in the use of lean management solutions and issues taken from game theory, can contribute to the further development of project management and help solve many practical problems identified within this area.

\section{Acknowledgements}

This paper was financed from the resources of the Silesian University of Technology, project no. BK-235/ROZ-1/2020 (13/010/BK_20/0042).

\section{References}

1. Ahn, M.J., Zwikael, O., and Bednarek, R. (2010). Technological invention to product innovation: A project management approach. International Journal of Project Management, 28(6), pp. 559-568. doi: https://doi.org/10.1016/j.ijproman.2009.11.001.

2. Al-Harbi, K.M.A.-S. (2001). Application of the AHP in project management. International Journal of Project Management, 19(1), pp. 19-27. doi: https://doi.org/10.1016/S02637863(99)00038-1.

3. Almarri, K., and Gardiner, P. (2014). Application of Resource-based View to Project Management Research: Supporters and Opponents. Procedia - Social and Behavioral Sciences, 119, pp. 437-445. doi: https://doi.org/10.1016/j.sbspro.2014.03.049.

4. Archibald, R. (2004.06.24). State of the Art of Project Management: 2004. $2^{\circ}$ Simposio di PM, Project Manager Role Evolution. Roma, Italia: Castlegandolfo.

5. Artto, K.A., and Wikstom K. (2005). What is project business? International Journal of Project Management, 23(5), pp. 343-353. doi: https://doi.org/10.1016/j.ijproman. 2005.03.005.

6. Åsgård, T. (2018). Health, safety and environment in the teaching of project management. The case of bachelor education in construction engineering in Norway. Procedia Computer Science, 138, pp. 688-696. doi: https://doi.org/10.1016/j.procs.2018.10.091.

7. Badri, A., Gbodossou, A., and Nadeau, S. (2012). Occupational health and safety risks: Towards the integration into project management. Safety Science, 50(2), pp. 190-198. doi: https://doi.org/10.1016/j.ssci.2011.08.008. 
8. Biedenbach, T., and Müller, R. (2011). Paradigms in project management research: examples from 15 years of IRNOP conferences. International Journal of Managing Projects in Business, 4(1), pp. 82-104. doi: https://doi.org/10.1108/17538371111096908.

9. Bilgin, G., Eken, G., Ozyurt, B., Dikmen, I., Birgonul, M.T., and Ozorhon, B. (2017). Handling project dependencies in portfolio management. Procedia Computer Science, 121, pp. 356-363. doi: https://doi.org/10.1016/j.procs.2017.11.048.

10. Bindera, J., Aillaud, L.IV, and Schilli. L. (2014). The Project Management Cocktail Model: An Approach for Balancing Agile and ISO 21500. Procedia - Social and Behavioral Sciences, 119, pp. 182-191. doi: https://doi.org/10.1016/j.sbspro.2014.03.022.

11. Bočková, K.H. (2015). What Game Theory and Poker can Teach us in Project Management. Procedia Economics and Finance, 34, pp. 97-104. doi: https://doi.org/10.1016/S22125671(15)01606-8.

12. Bočková, K.H., Sláviková, G., and Gabrhel, J. (2015). Game Theory as a Tool of Project Management. Procedia - Social and Behavioral Sciences, 213, pp. 709-715. doi: https://doi.org/10.1016/j.sbspro.2015.11.491.

13. Bredillet C. (2006). The future of project management: mapping the dynamics of project management field in action. In: D.I. Cleland, and R. Gareis (Eds.), Global project management handbook: planning, organizing, and controlling international projects. New York: McGraw-Hill.

14. Brown, A.W., Adams, J.D., and Amjad, A.A. (2007). The relationship between human capital and time performance in project management: A path analysis. International Journal of Project Management, 25(1), pp. 77-89. doi: https://doi.org/10.1016/j.ijproman. 2006.07.011.

15. Calabrese, G., and Mastroberardino, P. (2015). Professionalization and Dissemination of Project Management in Italy. Structuring an Organizational Field. Procedia Computer Science, 64, pp. 63-72. doi: https://doi.org/10.1016/j.procs.2015.08.464.

16. Chang, Y.-F., and Ishii, H. (2013). Fuzzy Multiple Criteria Decision Making Approach to Assess the Project Quality Management in Project. Procedia Computer Science, 22, pp. 928-936. doi: https://doi.org/10.1016/j.procs.2013.09.176.

17. Chen, Z., Lan, Y., and Ma, N. (2018). Career incentive contract design in project management under companies' competition and asymmetric information. Computers \& Industrial Engineering, 118, pp. 210-225. doi: https://doi.org/10.1016/j.cie.2018.02.024.

18. Chmielarz, W., and Zborowski, M. (2018). Determinants of Using Project Management in the Implementation of Information Systems. Procedia Computer Science, 126, pp. 12241236. doi: https://doi.org/10.1016/j.procs.2018.08.064.

19. Cicmil, S., and Hodgson, D. (2006). Making projects critical: An introduction. In: D. Hodgson, and S. Cicmil (Eds.), Making projects critical (pp. 1-25). New York: Palgrave Macmillan. 
20. Cicmil, S., Williams, T., Thomas, J., and Hodgson, D. (2006). Rethinking project management: researching the actuality of projects. International Journal of Project Management, 24(8), pp. 675-686. doi: https://doi.org/10.1016/j.ijproman.2006.08.006.

21. Cooke-Davies, T.J., and Arzymanow, A. (2003). The maturity of project management in different industries: An investigation into variations between project management models. International Journal of Project Management, 21(6), pp. 471-478. doi: https://doi.org/ 10.1016/S0263-7863(02)00084-4.

22. Crawford, L., Pollack, J., and England, D. (2006). Uncovering the trends in project management: journal emphases over the last 10 years. International Journal of Project Management, 24(2), pp. 175-184. doi: https://doi.org/10.1016/j.ijproman.2005.10.005.

23. De Magalhães, S.T., Magalhães, M.J., and Sá, V.J. (2015). Establishment ofAutomatization as a Requirement for Time Management Input Modules in Project Management Information Systems for Academic Activities - A Game Theory Approach. Procedia Computer Science, 64, pp. 1157-1162. doi: https://doi.org/10.1016/j.procs.2015.08.596.

24. Do Carmo Silva, M., and Simoes Gomes, C.F. (2015). Practices in Project Management According to Charles Handy's Organizational Culture Typologies. Procedia Computer Science, 55, pp. 678-687. doi: https://doi.org/10.1016/j.procs.2015.07.074.

25. Doloi, H.K. (2011). Understanding stakeholders' perspective of cost estimation in project management. International Journal of Project Management, 29(5), pp. 622-636. doi: https://doi.org/10.1016/j.ijproman.2010.06.001.

26. Ekrot, B., Kock, A., and Gemünden, H.G. (2016). Retaining project management competence - Antecedents and consequences. International Journal of Project Management, 34(2), pp. 145-157. doi: https://doi.org/10.1016/j.ijproman.2015.10.010.

27. Engwall, M. (2003). No project is an island: Linking projects to history and context. Research Policy, 32(5), pp. 789-808. doi: https://doi.org/10.1016/S0048-7333(02)00088-4.

28. Eriksson, P.E., Larsson, J., and Pesämaa, O. (2017). Managing complex projects in the infrastructure sector - A structural equation model for flexibility-focused project management. International Journal of Project Management, 35(8), pp. 1512-1523. doi: https://doi.org/10.1016/j.ijproman.2017.08.015.

29. Fallah-Mehdipour, E., Bozorg-Haddad, O., Tabari, M.M.R., and Marino, M.A. (2012). Extraction of decision alternatives in construction management projects: Application and adaptation of NSGA-II and MOPSO. Expert Systems with Applications, 39(3), pp. 27942803. doi: https://doi.org/10.1016/j.eswa.2011.08.139.

30. Gareis, R., and Huemann, M. (2007). Maturity models for the project oriented company. In: J.R. Turner (Eds.), The Gower Handbook of Project Management (pp. 183-208). Aldershot: Gower.

31. Geraldi, J., Turner, J.R., Maylor, H., Söderholm, A., Hobday, M., and Brady, T. (2008). Innovation in project management: Voices of researchers. International Journal of Project Management, 26(5), pp. 586-589. doi: https://doi.org/10.1016/j.ijproman.2008.05.011. 
32. Gomes, J., and Romão, M. (2016). Improving Project Success: A Case Study Using Benefits and Project Management. Procedia Computer Science, 100, pp. 489-497. doi: https://doi.org/10.1016/j.procs.2016.09.187. [46, 072].

33. Hall, N.G. (2012). Project management: recent developments and research opportunities. Journal of Systems Science and Systems Engineering, 21(2), pp. 129-143. doi: https://doi.org/10.1007/s11518-012-5190-5.

34. Heigermoser, D., García de Soto, B., Abbott, E.L.S., and Chua, D.K.H. (2019). BIM-based Last Planner System tool for improving construction project management. Automation in Construction, 104, pp. 246-254. doi: https://doi.org/10.1016/j.autcon.2019.03.01.

35. Hodgson, D., and Cicmil, S. (2006). Are projects real? The PMBoK and the legitimation of project management knowledge. In: D. Hodgson, and S. Cicmil (Eds.), Making projects critical (pp. 29-50). New York: Palgrave.

36. Hodgson, D., and Cicmil, S. (2008). The other side of projects: the case for critical project studies. International Journal of Managing Projects in Business, 1(1), pp. 142-152. doi: https://doi.org/10.1108/17538370810846487.

37. Hyväri, I. (2006). Project management effectiveness in project-oriented business organizations. International Journal of Project Management, 24(3), pp. 216-225. doi: https://doi.org/10.1016/j.ijproman.2005.09.001.

38. Hyväri, I. (2016). Roles of Top Management and Organizational Project Management in the Effective Company Strategy Implementation. Procedia - Social and Behavioral Sciences, 226, pp. 108-115. doi: https://doi.org/10.1016/j.sbspro.2016.06.168.

39. Ingasona, H.Th., and Shepherd, M.M. (2014). Mapping the Future for Project Management as a Discipline - For more Focused Research Efforts. Procedia - Social and Behavioral Sciences, 119, pp. 288-294. doi: https://doi.org/10.1016/j.sbspro.2014.03.033.

40. Jugdev, K., Mathur, G., and Fung, T.S. (2007). Project management assets and their relationship with the project management capability of the firm. International Journal of Project Management, 25(6), pp. 560-568. doi: https://doi.org/10.1016/j.ijproman. 2007.01.009.

41. Jugdev, K., Thomas, J., and Delisle, C. L. (2001). Rethinking project management: old truths and new insights. International Journal of Project Management, 7(1), pp. 36-43.

42. Khameneh, A.H., Taheri, A., and Ershadi, M. (2016). Offering a Framework for Evaluating the Performance of Project Risk Management System. Procedia - Social and Behavioral Sciences, 226, pp. 82-90. doi: https://doi.org/10.1016/j.sbspro.2016.06.165.

43. Kolltveita, B.J., Karlsena, J.T., and Grønhaug, K. (2007). Perspectives on project management. International Journal of Project Management, 25(1), pp. 3-9. doi: https://doi.org/10.1016/j.ijproman.2005.12.002.

44. Koskela, L., and Howell, G.A. (2002). The underlying theory of project management is obsolete. Proceedings of the PMI Conference, July 2002, Seattle, PMI, pp. 293-302. 
45. Kwak, Y.H., and Anbari, F.T. (2009). Analyzing project management research: perspectives from top management journals. International Journal of Project Management, 27(5), pp. 435-446. doi: https://doi.org/10.1016/j.ijproman.2008.08.004.

46. Lachhab, M., Béler, C., Solano-Charris, E.L., and Coudert, T. (2017). Towards an Integration of Systems Engineering and Project Management Processes for a Decision Aiding Purpose. IFAC-PapersOnLine, 50(1), pp. 7266-7271. doi: https://doi.org/ 10.1016/j.ifacol.2017.08.1379.

47. Legault, M.-J., and Chasserio, S. (2012). Professionalization, risk transfer, and the effect on gender gap in project management. International Journal of Project Management, 30(6), pp. 697-707. doi: https://doi.org/10.1016/j.ijproman.2011.11.004.

48. Liang, T.-F. (2009). Fuzzy multi-objective project management decisions using two-phase fuzzy goal programming approach. Computers \& Industrial Engineering, 57(4), pp. 14071416. doi: https://doi.org/10.1016/j.cie.2009.07.010.

49. Liang, T.-F. (2010). Applying fuzzy goal programming to project management decisions with multiple goals in uncertain environments. Expert Systems with Applications, 37(12), pp. 8499-8507. doi: https://doi.org/10.1016/j.eswa.2010.05.026.

50. Lim, A., Ma, H., Rodrigues, B., Teck Tan, S., and Xiao, F. (2011). New concepts for activity float in resource-constrained project management. Computers \& Operations Research, 38(6), pp. 917-930. doi: https://doi.org/10.1016/j.cor.2010.10.004.

51. Lückmann, P., and Färber, K. (2016). The Impact of Cultural Differences on Project Stakeholder Engagement: A Review of Case Study Research in International Project Management. Procedia Computer Science, 100, pp. 85-94. doi: https://doi.org/ 10.1016/j.procs.2016.09.127.

52. Marquès, G., Gourc, D., and Lauras, M. (2011). Multi-criteria performance analysis for decision making in project management. International Journal of Project Management, 29(8), pp. 1057-1069. doi: https://doi.org/10.1016/j.ijproman.2010.10.002.

53. Martin, A. (2000). A simulation engine for custom project management education. International Journal of Project Management, 18(3), pp. 201-213. doi: https://doi.org/ 10.1016/S0263-7863(99)00014-9.

54. Masár, M., Hudáková, M., Šimák, L., and Brezina, D. (2019). The current state of project risk management in the transport sector. Transportation Research Procedia, 40, pp. 11191126. doi: https://doi.org/10.1016/j.trpro.2019.07.156.

55. Maylor, H. (2001). Beyond the Gantt chart - Project management moving on. European Management Journal, 19(1), pp. 92-100. doi: https://doi.org/10.1016/S02632373(00)00074-8.

56. Morris, P.W.G., Crawford, L., Hodgson, D., Shepherd, M., and Thomas, J. (2006). Exploring the role of formal bodies of knowledge in defining a profession - The case of project management. International Journal of Project Management, 24(8), pp. 710-721. doi: https://doi.org/10.1016/j.ijproman.2006.09.012. 
57. Morris, P.W.G., Jamieson, A., and Shepherd, M.M. (2006b). Research updating the APM Body of Knowledge 4th edition. International Journal of Project Management, 24(6), pp. 461-473. doi: https://doi.org/10.1016/j.ijproman.2006.02.002.

58. Morris, P.W.G., Patel, M.B., and Wearne, S.H. (2000). Research into revising the APM project management body of knowledge. International Journal of Project Management, 18(3), pp. 155-164. doi: https://doi.org/10.1016/S0263-7863(99)00068-X.

59. Morris, P.W.G., Pinto, J.K., and Söderlund, J. (2011). Introduction: towards the third wave of project management. In: P.W.G. Morris, J.K. Pinto, and J. Söderlund (Eds.), The Oxford handbook of project management (pp. 1-11). Oxford: Oxford University Press.

60. Mossalama, A., and Arafab, M. (2017). Governance model for integrating organizational project management (OPM) with corporate practices. HBRC Journal, 13(3), pp. 302-314. doi: https://doi.org/10.1016/j.hbrcj.2015.08.003.

61. Okoro, T. (2016). Diverse Talent: Enhancing Gender Participation in Project Management. Procedia - Social and Behavioral Sciences, 226, pp. 170-175, doi: https://doi.org/ 10.1016/j.sbspro.2016.06.176.

62. Padalkar, M., and Gopinath, S. (2016). Six decades of project management research: Thematic trends and future opportunities. International Journal of Project Management, 34(7), pp. 1305-1321. doi: https://doi.org/10.1016/j.ijproman.2016.06.006.

63. Pheng, L.S., and Leong, C.H.Y. (2000). Cross-cultural project management for international construction in China. International Journal of Project Management, 18(5), pp. 307-316. doi: https://doi.org/10.1016/S0263-7863(99)00027-7.

64. Pollack, J. (2007). The changing paradigms of project management. International Journal of Project Management, 25(3), pp. 266-274. doi: https://doi.org/10.1016/j.ijproman. 2006.08.002.

65. Pollack, J., and Adler, D. (2015). Emergent trends and passing fads in project management research: a scientometric analysis of changes in the field. International Journal of Project Management, 33(1), pp. 236-248. doi: https://doi.org/10.1016/j.ijproman.2014.04.011.

66. Ponsteen, A., and Kusters, R.J. (2015). Classification of Human- and Automated Resource Allocation Approaches in Multi-Project Management. Procedia - Social and Behavioral Sciences, 194, 165-173. doi: https://doi.org/10.1016/j.sbspro.2015.06.130.

67. Project Management Institute (2013). A Guide to the Project Management Body of Knowledge (PMBOK® Guide). USA, Newtown Square: Project Management Institute.

68. Rehor, P., and Vrchota, J. (2018). Remuneration in small and middle-sized enterprises with project management. Procedia Computer Science, 138, pp. 829-834. doi: https://doi.org/ 10.1016/j.procs.2018.10.108.

69. Rivera, A., and Kashiwagi, J. (2016). Identifying the State of the Project Management Profession. Procedia Engineering, 145, pp. 1386-1393. doi: https://doi.org/10.1016/ j.proeng.2016.04.204. 
70. Saidoun, A. (2016). Successful Project Management in North Africa with Intercultural Competence. Procedia - Social and Behavioral Sciences, 226, pp. 218-225. doi: https://doi.org/10.1016/j.sbspro.2016.06.182.

71. Sanchez, O.P., Terlizzi, M.A., and de Moraes, H.R.D.O.C. (2017). Cost and time project management success factors for information systems development projects. International Journal of Project Management, 35(8), pp. 1608-1626. doi: https://doi.org/10.1016/ j.ijproman.2017.09.007.

72. Shenhar, A.J. (2001). One size does not fit all projects: exploring classical contingency domains. Management Science, 47(3), pp. 394-414. doi: https://doi.org/10.1287/ mnsc.47.3.394.9772.

73. Smyth, H.J., and Morris, P.W. (2007). An epistemological evaluation of research into projects and their management: methodological issues. International Journal of Project Management, 25(4), pp. 423-436. doi: https://doi.org/10.1016/j.ijproman.2007.01.006.

74. Söderlund, J. (2004). On the broadening scope of the research on projects: a review and a model for analysis. International Journal of Project Management, 22(8), pp. 655-667. doi: https://doi.org/10.1016/j.ijproman.2004.05.011.

75. Söderlund, J., (2004b). Building theories of project management: past research, questions for the future. International Journal of Project Management, 22, pp. 183-191. doi: https://doi.org/10.1016/S0263-7863(03)00070-X.

76. Söderlund, J., and Maylor, H. (2012). Project management scholarship: Relevance, impact and five integrative challenges for business and management schools. International Journal of Project Management, 30(6), pp. 686-696. doi: https://doi.org/10.1016/j.ijproman. 2012.03.007.

77. Sohi, A.J., Hertogh, M., Bosch-Rekveldt, M., and Blom, R. (2016). Does Lean \& Agile Project Management Help Coping with Project Complexity? Procedia - Social and Behavioral Sciences, 226, pp. 252-259. doi: https://doi.org/10.1016/j.sbspro.2016.06.186.

78. Svejvig, P., and Andersen, P. (2015). Rethinking project management: a structured literature review with a critical look at the brave new world. International Journal of Project Management, 33(2), pp. 278-290. doi: https://doi.org/10.1016/j.ijproman.2014.06.004.

79. Teller, J., and Kock, A. (2013). An empirical investigation on how portfolio risk management influences project portfolio success. International Journal of Project Management, 31(6), pp. 817-829. doi: https://doi.org/10.1016/j.ijproman.2012.11.012.

80. Tenera, A., and Pinto, L.C. (2014). A Lean Six Sigma (LSS) Project Management Improvement Model. Procedia - Social and Behavioral Sciences, 119, pp. 912-920. doi: https://doi.org/10.1016/j.sbspro.2014.03.102.

81. Themistocleous, G., and Wearne, S. (2000). Project management topic coverage in journals. International Journal of Project Management, 18(1), pp. 7-11. doi: https://doi.org/ 10.1016/S0263-7863(99)00030-7. 
82. Turner, J.R., Anbari, F., and Bredillet, C. (2013). Perspectives on research in project management: the nine schools. Glob Bus Perspect, 1(1), pp. 3-28. doi: https://doi.org/ 10.1007/s40196-012-0001-4.

83. Turner, J.R., Ledwith, A., and Kelly, J. (2010). Project management in small to mediumsized enterprises: Matching processes to the nature of the firm. International Journal of Project Management, 28(8), pp. 744-755. doi: https://doi.org/10.1016/j.ijproman. 2010.06.005.

84. Uchitpe, M., Uddin, S., and Lynn, C. (2016). Predicting the Future of Project Management Research. Procedia - Social and Behavioral Sciences, 226, pp. 27-34. doi: https://doi.org/ 10.1016/j.sbspro.2016.06.158.

85. Van Der Velde, R.R., and Van Donk, D.P. (2002). Understanding bi-project management: engineering complex industrial construction projects. International Journal of Project Management, 20(7), pp. 525-533. doi: https://doi.org/10.1016/S0263-7863(01)00053-9.

86. Vicente-Oliva, S., Martínez-Sánchez, Á., and Berges-Muro, L. (2015). Research and development project management best practices and absorptive capacity: Empirical evidence from Spanish firms. International Journal of Project Management, 33(8), pp. 1704-1716. doi: https://doi.org/10.1016/j.ijproman.2015.09.001.

87. Viglioni, T.G.A., Cunha, J.A.O.G., and Moura, H.P. (2016). A Performance Evaluation Model for Project Management Office Based on a Multicriteria Approach. Procedia Computer Science, 100, pp. 955-962. doi: https://doi.org/10.1016/j.procs.2016.09.257.

88. Vilhelmsdottir, A.S., Kristjansdottir E., and Ingason H.T. (2016). What can be Learnt from the Icelandic National Team's Managers, in Project Management and in Shaping Group Dynamics? Procedia - Social and Behavioral Sciences, 226, pp. 278-285. doi: https://doi.org/10.1016/j.sbspro.2016.06.189.

89. Vlahov, R.D., Mišić, S., and Radujković, M. (2016). The Influence of Cultural Diversity on Project Management Competence Development - The Mediterranean Experience. Procedia - Social and Behavioral Sciences, 226, pp. 463-469. doi: https://doi.org/10.1016/ j.sbspro.2016.06.212.

90. Winter, M., Smith, C., Morris, P., and Cicmil, S. (2006). Directions for future research in project management: the main findings of a UK government funded research network. International Journal of Project Management, 24(8), pp. 638-649. doi: https://doi.org/ 10.1016/j.ijproman.2006.08.009.

91. Yan, Y., Kuphal, T., and Bode, J. (2000). Application of multiagent systems in project management. International Journal of Production Economics, 68(2), pp. 185-197. doi: https://doi.org/10.1016/S0925-5273(00)00082-7.

92. Yang, M.-F., and Lin, Y. (2013). Applying fuzzy multi-objective linear programming to project management decisions with the interactive two-phase method. Computers \& Industrial Engineering, 66(4), pp. 1061-1069. doi: https://doi.org/10.1016/j.cie. 2013.08.009. 
93. Žarković, N., Vrečko, I., and Barilović, Z. (2014). Creating Holistic Project-knowledge Society through Project Management Education in Research and Development. ProcediaSocial and Behavioral Sciences, 119, pp. 210-218. doi: https://oi.org/10.1016/ j.sbspro.2014.03.025.

94. Zwikael, O., Shimizu, K., and Globerson, S. (2005). Cultural differences in project management capabilities: A field study. International Journal of Project Management, 23(6), pp. 454-462. doi: https://doi.org/10.1016/j.ijproman.2005.04.003. 